\title{
Toplu İş Sözleşmesinden Dayanışma Aidatı Ödeyerek Geçmişe Dönük Yararlanma -Anayasa Mahkemesi Kararı Üzerine Düşünceler-
}

\author{
M. Polat SOYER ${ }^{1}$ \\ ORCID: 0000-0001-6291-747X \\ DOI: $10.54752 /$ ct.1060775
}

Öz: Toplu iş sözleşmesine taraf işçi sendikasına üye olmayan işçilerin dayanışma aidatı ödemek suretiyle sözleşmeden geçmişe dönük yararlanmaları, iş hukukunun en önemli sorunlarından biridir. Bunun nedeni, konunun, kolektif sendika özgürlüğü ile sendikaya üye olmama (negatif sendika) özgürlügünün kesiştiği bir alanı ilgilendirmesidir. Anayasa Mahkemesi, 30 Aralık 2020 tarihinde, negatif sendika özgürlüğ̈nün korunması konusunda önemli bir karar vermiştir. Ancak bu kararın, ele alınan konu hakkındaki görüş ayrılıklarını ortadan kaldıracağını beklemek mümkün görünmemektedir. $\mathrm{Bu}$ incelemede, anılan karar hakkındaki düşüncelerimiz ortaya konulmaktadır.

Anahtar Kelimeler: Kolektif sendika özgürlüğü, negatif sendika özgürlüğü, toplu iş sözleşmesi, dayanışma aidatı, geçmişe dönük yararlanma, Anayasa Mahkemesi.

Retrospectively Benefiting from Collective Labor Agreement by Paying Solidarity Dues -Considerations on the Decision of the Constitutional Court-

Abstract: Retrospectively benefiting of unorganized (non-union) workers from collective labor agreement by paying solidarity dues is one of the most important problems of labor law. This is because it concerns an area where the freedom to organize (collectively) and the freedom not to join a union intersect. The Constitutional Court decided on December 30, 2020 about the protection of the freedom not to join a union. However it does not seem possible to expect that this decision will eliminate the disagreements regarding the problem of retrospectively benefiting of unorganized (non-union) workers. This article reveals my thoughts on this important decision of the Constitutional Court.

\footnotetext{
${ }^{1}$ Prof. Dr. Yakındoğu Üniversitesi Hukuk Fakültesi

Makale Geliş Tarihi: 08.07.2021 - Makale Kabul Tarihi:03.12.2021
} 
Keywords: Freedom to organize (collectively), freedom of not to join a union, collective labor agreement, solidarity dues, retrospectively benefiting, Constitutional Court.

\section{Giriş}

Toplu iş sözleşmesinin hangi işçiler hakkında uygulanacağı, toplu sözleşme hukukunun en tartışmalı konuları arasında yer almaktadır. Soruna karşılaştırmalı hukuk açısından bakıldığında, çeşitli ülkelerde farklı sistemlerin benimsenmiş olduğu; ancak hiçbir sistemin, tüm çevreleri tatmin eden bir çerçeve ortaya koyamadığ1 görülmektedir. Bu manzaranın temel nedeni, konunun, kolektif ve negatif sendika özgürlügünü karşlıklı olarak önemli ölçüde etkileyen/ilgilendiren bir özellik taşımasıdır. Her iki özgürlük arasındaki optimal denge ise, bugüne kadar ne yazık ki, kurulamamıştır. Bu incelemenin amacı, toplu iş sözleşmesinin kişiler açısından uygulanma alanı ile ilgili belli başlı sistemleri kısaca hatıllattıktan sonra, Türk Hukukunda uygulanmakta olan modelin gelişim çizgisini ve bu alanda ortaya çıkan son gelişmeleri; özellikle, sözleşmeye taraf sendikaya üye olmayanların toplu iş sözleşmesinden -geçmişe dönük- yararlanmaları konusunda ortaya çıkan yeni tabloyu -karşılaştırmalı hukuktan da yararlanarak- değerlendirmektir.

\section{Toplu İş Sözleşmesinin Kişiler Açısından Uygulanma Alanı ile İlgili Belli Başlı Sistemler}

Toplu iş sözleşmesinden hangi işçilerin yararlanacakları konusunda başlıca üç sistem olduğu söylenebilir: Bunlardan örneğin Amerika Birleşik Devletleri modelinde, toplu iş sözleşmeleri işyerinde çalışan tüm işçiler hakkında uygulanmaktadır. Gerçekten, önce -Wagner Kanunu olarak da anılan- 1935 tarihli yasa [National Labor Relations Act Sec. 9 (a)]; sonra da onun yerini alan -ve Taft Hartley Kanunu olarak da anılan- 1947 tarihli yasa [Labor Management Relations Act (\ 159)], işçilerin çoğunluğunu temsil eden sendikanın, işyerinde sendikalısendikasız tüm işçilerin temsilcisi olduğunu ve yaptı̆̆ toplu iş sözleşmesinin bütün işçilere uygulanacağını öngörmüş bulunmaktadır (bkz. Goldman, 1996: 22, 246). Diğer taraftan, Kara Avrupa hukuk ailesine mensup olmalarına rağmen, Avusturya ve Fransa'da da benzer bir modelin kabul edildiği görülmektedir. Gerçekten, Avusturya'da hem 6 Mays 1947 tarihli yasada (Kollektivvertragsgesetz \10; bkz. Sachers, 1958: 6) hem de onun yerini alan 14 Aralı 1973 tarihli yasada (Arbeitsverfassungsgesetz $\int 12$ Abs. 1; bkz. Stöckli, 1999: Art. 356 b N. 1; Gagawuczuk, 2013: 10) toplu iş sözleşmesinin sendika üyesi olmayan işçiler hakkında da uygulanacağı hükme bağlanmıştır. Fransız İş Kodunda da toplu iş̧ sözleşmesinin kişiler açısından uygulanma alanı konusunda sendikalı-sendikasız işçi 
ayırımı yapılmamıştır (bkz. Stöckli: 1999 Art. 356b N. 1)22. Belirtmek gerekir ki, toplu iş sözleşmesinin işyerinde çalışan tüm işçilere uygulanması yönündeki model, üyeliği çekici kılmak için, sendikaları toplu sözleşme dişında, işçiler için yararlı başka çalsşma ve hizmetlere teşvik edeceği ve negatif sendika özgürlügünün ihlali ve korunması konusundaki tartısmalara son vereceği gibi bir varsayımı da beraberinde getirmektedir. Ancak bu model, sendikasız işçileri hiçbir maddî ve manevî külfete katlanmadan sendikalı işçilerle aynı yararlara kavuşturması nedeniyle de eleştirilmektedir (Bkz. Biedenkopf, 1961: 348 ve orada dn. 26. Söz konusu işçilerin "bedavac1/free rider/Trittbrettfahrer" olarak da anılmalarının nedeni budur).

Buna karşl1ık Alman Hukukunda, toplu iş sözleşmesi ile kural konulabilmesi, sendika üyelerinin, üyelik ilişkisi nedeniyle sendikalara norm koyma konusunda bir meşruiyet tanımış oldukları düşüncesine dayanır (bkz. Biedenkopf, 1964: 59 vd; 231; Zöllner, 1983: 339). Bu nedenledir ki, toplu iş sözleşmesi ile, sözleşmeye taraf olanlara, üyeleriyle sınırlı bir kural koyma olanağı tanındığ1 kabul edilir (bkz. Zöllner, 1983: 339). Nitekim, bu düşünce doğrultusunda (Alman) Toplu Sözleşme Kanunu (Tarifvertragsgesetz), iş sözleşmesinin içeriği, yapılması ve sona ermesi ile ilgili alanda toplu sözleşme erkini, taraf kuruluşlara üye olanlarla sinırlı tutmuştur (\$ 4 Abs. 1 TVG; Zöllner 1983: 340). Ne var ki, toplu sözleşme normlarının sadece sendikalı işçilere uygulanması ile ilgili bu hükme rağmen, Federal Almanya'da toplu iş sözleşmesi ile bağlı olan işverenler, öteden beri, toplu sözleşme normlarını sendika üyesi olmayan işçilere de uygulama yoluna gitmişlerdir. Bu tutumun pek çok nedene dayandığı tahmin edilmektedir: Bunlar arasında ilk akla gelenler, işverenlerin, sendika üyeliği konusunda hiçbir araştırma yapmamaları veya işçiler arasında sendika üyeliği bakımından bir ayırım gözetmeyi rasyonalizasyon açısından doğru bulmamaları; hatta, "haksız" görmeleri veyahut aksi yönde bir tutumun sendika üyeliğini teşvik edeceğinden endişe etmeleridir (bkz. Zöllner, 1983: 341). Ancak bu uygulama, zaman içinde, işçi sendikalarını, toplu iş sözleşmelerine, ayırımcılık hükümleri (Differenzierungsklauseln) denilen bazı "sınırlayıcı" düzenlemeler koymaya yöneltmiştir. Bunlar arasında konumuzu en çok ilgilendirenler, sendika üyesi olmayanlara toplu sözleşme normlarının uygulanmasını yasaklayan hükümlerdir (Tarifausschlussklauseln). Bununla birlikte, belirtmek gerekir ki, bu tür düzenlemeler, Alman Hukukunda meşru sayllmamakta; bu yolla, sendika üyesi olmayanların sözleşme özgürlüğüne müdahalede bulunulduğu kabul edilmektedir (bkz. Biedenkopf, 1961: 98; Zöllner, 1983: 341).

Nihayet, toplu iş sözleşmesinin kişiler bakımından uygulanma alanı ile ilgili üçüncü model, toplu iş sözleşmesi ile bağlllı̆ın taraf sendika üyeliğine dayandığını; ancak üye olmayan işçilerin de toplu iş sözleşmesinden dayanışma aidatı ödemek

${ }^{2}$ Fransız İş Kodu (CT) Art.L.135-1. 12.3.2007 tarihinde yapılan değişiklikler sonucunda ise, bu madde yasada Art. L.2254-1 olarak yer almıştır. Konu ile ilgili madde numaralarında meydana gelen farklılıklar hakkında beni aydınlatan değerli meslektaşım Sayın Prof. Dr. Ali Güzel'e tekrar içtenlikle teşekkür ederim. 
suretiyle yararlanabileceklerini kabul eden sistemdir. Bu sistemin en önde gelen sahibi ve uygulayıc1sı ise, İsviçre'dir. Gerçekten, İsviçre'de daha 1956 ve daha sonra 1971 yılında İsviçre Borçlar Kanununda yapılan düzenlemelerde, bu modelin tercih edildiği görülmektedir (konunun İsviçre Hukukundaki gelişimi için bkz. Schweingruber ve Bigler, 1985: 51 vd). İsviçre Hukukunda da toplu iş sözleşmesinin normatif etkisi kural olarak toplu iş sözleşmesi ile bağlı olanlar hakkında söz konusu olmakta ve sözleşme ile bağlılık taraf sendikaya üyelik esasına dayanmaktadır (bkz. Stöckli 1999: Art. 356 b. N. 2; Art. 356 N. 62), Ne var ki, yasada, taraf sendikaya üye olmayan münferit işverenin veya toplu iş sözleşmesi ile bağlı olan işveren nezdinde çalışan bir iş̧̧inin de, "tarafların muvafakati" ile, toplu iş sözleşmesine "katılabileceğì" (Anschluss) öngörülmekte (Art. 356 b Abs. 1 OR) ve katılmanın toplu iş sözleşmesi ile daha ayrıntılı olarak düzenlenebileceği; yargıcın da, özellikle, kararlaştırılan (aşırı) aidat tutarını geçersiz sayabileceği veya meşru sınırlara indirebileceği belirtilmektedir (Art. 356 b Abs. 2 OR). Her ne kadar maddede sadece "aidat" ifadesi geçmekte ise de, öğretide bununla, iş yaşamında yaygın bir biçimde uygulanmakta olan "dayanışma aidatı"nın kastedildiği belirtilmektedir (bkz. Schweingruber ve Bigler, 1985: 54).

\section{Türk Hukukunda Uygulanan Sistem ve Toplu İş Sözleşmesinden Dayanışma Aidatı Ödeyerek Yararlanmanın Başlangıcı}

Bilindiği gibi, hukukumuzda da, 275 sayılı yasadan itibaren toplu iş sözleşmesi ile bağlılık, taraf sendikaya üyelik esasına dayandırılmış fakat üye olmayanların sözleşmeden yararlanabilmeleri -farklı esaslarla da olsa- İsviçre Hukukundaki dayanışma aidatı müessesesi ile gerçekleştirilmeye çalışılmıştır [275 Sayılı Yasa, md. 7 b. 3; 2822 Sayll Yasa, md. 9, f. 1, 3; 6356 Sayll Yasa, md. 39 (1) ve (4)]. Ne var ki, Türkiye'de -saptayabildiğim kadarıly İsviçre Hukukunda hiç rastlanmayan- bir sorunla da karşılaşılmıştır: Gerçekten, 275 Sayılı yasanın taraf işçi sendikasına üye olmayanların toplu iş sözleşmesinden yararlanabilmelerini dayanışma aidatı ödemelerine bağlı tutmakla yetinen (md. 7 b.3); 2822 sayılı yasanın da, dayanışma aidatı ödeyerek toplu iş sözleşmesinden yararlanmanın "talep tarihinden itibaren" geçerli olacağını öngören ve fakat sözleşmenin imzalanmasından önceki taleplerin yararlanmanın başlangıcı bakımından dikkate alınıp alınmayacağı konusunda herhangi bir çözüm getirmemiş olan düzenlemesi (md. 9 f.2 son cümle) karşısında, uygulamada sıklıkla, toplu iş sözleşmesinin yapılmasindan önce yararlanma talebinde bulunulduğuna; imzalanan toplu iş sözleşmesinin -neredeyse hemen daima- geçmişe etkili olarak yürürlüğe konulduğu hallerde de, sözleşmeden geriye dönük olarak -talep tarihinden itibaren- yararlanmak istendiğine tanık olunmuştur. Bu uygulama ise, görüş ayrılıklarına yol açtı̆̆ gibi, Yargıtay’ı da uzun süre meşgul etmiştir: 
Gerçekten, o dönemde bir görüş, toplu iş sözleşmesinden dayanışma aidatı ödeyerek talep tarihinden itibaren yararlanılabileceğini; ancak, henüz imzalanmamış bir toplu iş sözleşmesinden yararlanma talebinde bulunulamayacağını; böyle bir talepte bulunulmuşsa, yararlanmanın imza tarihinden itibaren söz konusu olabileceğini; bu nedenlerle de sözleşmeden geçmişe dönük bir biçimde yararlanmanın mümkün olamayacağını savunmuştur ${ }^{3}$. Bu düşüncede olan yazarlardan bir kısm1, aksi düşüncenin, kolektif sendika özgürlüğünü ihlal edeceğini de ileri sürmüştür (Eyrenci, 1980: 10; aksi düşüncenin üye olmayanlar lehinde bir sonuç ortaya çıkaracağ1 yönünde, Narmanlıŏ̆lu, 1991: 223). Yargitay da, toplu iş sözleşmesinin imzalanmasından önce dayanışma aidatı ödeyerek yararlanma talebinde bulunan işçiye, geçmişe dönük yararlanma hakkının tanınamayacağını istikrarlı bir biçimde karara bağlamıştır . Buna karşıllk, aksi yöndeki bir görüş, yasanın, sadece yararlanmayı talep tarihinden itibaren geçerli gördügünü; talebin ne zaman yapılacağını ise, düzenlemediğini; imza tarihinden önce de talepte bulunulabileceğini; yararlanma konusunda üyelerle üye olmayanların eşit durumda olmaları gereğinden hareketle, dayanışma aidatı ödeyerek toplu iş sözleşmesinden geçmişe dönük olarak yararlanmanın mümkün olduğunu ileri sürmüştür5. $\mathrm{Bu}$ "sonucu" benimseyen bazı yazarlar ise, görüşlerini, imza tarihinde dayanışma aidatı ödeyerek yararlanma talebinde bulunanların, sözleşmenin bütün hükümlerinden yararlandırılmaları gerektiği için, geçmişe etki ile ilgili maddenin onlar hakkında da hüküm ifade edecek olması düşüncesiyle desteklemişlerdir (bkz. Oğuzman, 1987: 75; aynı yazar, İş Hukuku ve Sosyal Güvenlik Hukuku Türk Milli Komitesi Tarafindan Ankara'da Düzenlenen Toplu İş Sözleşmesine İlişkin Temel Sorunlar, 1990 Semineri, Genel Görüşme, 167; 275 sayılı yasa zamanında benzer yönde, Çelik, 1980. Ancak son yazar, 2822 sayılı yasa döneminde yayınladığı bir başka incelemesinde, yararlanmanın talep tarihinden itibaren geçerli olacağını öngören yasal düzenleme karşısında geçmişe dönük yararlanma olanağını savunmanın zor olduğunu ifade etmektedir. Bkz. Çelik, 1990: 151).

\footnotetext{
3 Örneğin bkz. Eyrenci, 1980: İHU TSGLK 7 (No: 8; 10); Şahlanan, 1992: 147; Tunçomağ ve Centel, 2008: 387-388; Narmanlıoğlu, 1991: 220-221; Ulucan, 1986: 121-122; Tuncay ve Kutsal, 2019: 313-314; Gerek, 1999: 140-142; Keser, 1994: 9-10; Sümer, 2007: 254-255; Subaş1, 2009: 190-193; Özdemir, 2002: 156.

4 Örneğin bkz. Yarg. 9. HD 21.4.1980, E. 1980/4205, K. 1980/3655, İHU TSGLK 7 No.7, Çelik'in incelemesiyle; Yarg. 28.7.1980, E. 1980/8560, K. 1980/8357, İHU TSGLK 7 No. 8, Eyrenci'nin incelemesiyle; Yarg. HGK 16.4.1982, E. 1982/9-244, K. 1982/404, kazanci.com; Yarg. 9. HD 16.4.1985, E. 2154, K. 4167, Yarg. HGK'nun 23.5.1986 tarih ve E.9-459,K. 571 sayılı kararı içinde; Yarg. HGK 23.5.1986, E. 9-459, K. 571, kazanci.com; Yarg. 9. HD 15.02.2006, E. 2005/20647, K. 2006/3670, Sicil, İş Hukuku Dergisi, Haziran 2006, Sa. 2, s. 122; kararın incelenmesi, Caniklioğlu 2006; 123 vd; kararın Hukuk Genel Kurulu'na intikali üzerine, aynı yönde, Yarg HGK 31.1.2007, E. 9-27, K. 47, kazanci.com. ${ }^{5}$ Bkz. Reisoğlu, 1986: 147-148; Aktay (Aktay/Arıcı ve Kaplan), 2011 içinde: 464; Ekmekçi, 1996: $162 \mathrm{vd}$.
} 
Belirtmek gerekir ki, 2822 Saylı Toplu İş Sözleşmesi Grev ve Lokavt Kanunu'nun değiştirilmesi ile ilgili süreçte, Çalışma ve Sosyal Güvenlik Bakanlığı'nın görevlendirdiği üç kişilik bir bilim kurulu tarafından hazırlanan taslakta $^{6}$, toplu iş sözleşmesinden dayanışma aidatı ödemek suretiyle yararlanma konusundaki taleplerin, sözleşmenin imzalanmasından sonra geçerli olacağ1 öngörülmüş ve bu değişiklik önerisi bazı yazarlar tarafından, sendika üyeliğini teşvik ettiği gerekçesiyle olumlu karşılanmıştır (bkz. Uçum ve Okcan, 2004: 409-410; Taşkent, 2004: 263). Nihayet, 6356 sayll yasa, imza tarihinden önceki taleplerin imza tarihi itibarıyla hüküm doğuracağını hükme bağlayarak [md. 39 (4) son cümle] bu alandaki görüş ayrılıklarını ortadan kaldırmış fakat tartışmaları sona erdirememiştir:

Gerçekten, toplu iş sözleşmesinden dayanışma aidatı ödeyerek yararlanmanın sadece imza tarihinden sonrası için mümkün kılınması, sözleşmeden dayanışma aidatı yoluyla yararlanmak isteyenleri taraf sendikaya üye olmaya zorlayacağı gerekçesiyle, 2822 sayılı yasa döneminden başlayarak günümüze kadar bazı yazarlar tarafından, anayasal güvence altında olan negatif sendika özgürlüğüne aykırı görülmüştür [bkz. Çelik, 1990: 151-152 (yazara göre, negatif sendika özgürlügüne aykırı düşen bir kolektif sendika özgürlüğünden de söz edilemez); Çelik/Caniklioğlu ve Canbolat, 2020: 1038, 1068; Canbolat, 2002: 19; Ekmekçi, 1996: 163; aynı yazar, 2021: 395; anayasaya aykırılık görüşünün yerinde olduğu yönünde, Gümrükçüoğlu, 2018: 294; geçmişe etkili sözleşmeden yararlanma konusunda sendikaya üye olan işçilerle üye olmayanlar arasında gereksiz bir ayırım yaratıldığ1; kolektif sendika özgürlüğü ile negatif sendika özgürlüğü arasında bir dengenin kurulabilmesi için, toplu iş sözleşmesinden yararlanma konusunda taraf sendikaya üye olanlarla olmayanlar arasında eşitlik sağlanması gerektiği yönünde, Özkaraca, 2014: 191-195; aynı yazar, 2016: 295). Bu nedenle, yasada yapilacak bir değişiklikle, imza tarihinde aidat ödemeyi kabul edenlerin de yürürlük tarihinden itibaren sözleşmeden yararlanmalarının sağlanması gerektiği; bunun serbestçe sendika seçme özgürlüğ̈ne uygun düşeceği belirtilmiştir (bkz. Çelik/Caniklioğlu ve Canbolat, 2020: 1068).

\section{Anayasa Mahkemesi'nin İptal Kararı ve Düşündürdükleri}

Bu kadar uzun bir zamana yayılan sorun, nihayet, Bakırköy 16. İş Mahkemesi tarafindan itiraz yolu ile Anayasa Mahkemesi'ne götürülmüş, Yüksek Mahkeme de, iki üyenin karş1 oyu ile, 6356 sayılı Sendikalar ve Toplu İş Sözleşmesi Kanunu'nun

${ }^{6}$ Toplu iş ilişkileri alanında yapılmak istenen değişikliklerle ilgili çalışmaların gelişimi hakkında ayrıntılı bilgi için bkz. Pirler, Bülent, Toplu İş İlişkileri Sistemimizde Yeni Döneme Başlarken Geride Bıraktıklarımız, Dokuz Eylül Üniversitesi Hukuk Fakültesi Dergisi Cilt: 15, Özel S., 2013 (Basım Yll: 2014), Prof. Dr. M. Polat Soyer'e Armağan, s. 883-912. 
39. maddesinin (4) numaralı fikrasının dördüncü cümlesinin Anayasa'ya aykırı olduğu sonucuna vararak, iptaline karar vermiştir (AYM 30.12.2020 E. 2020/57, K. 2020/83, RG 3.3.2021, Sa. 31412).

Yüksek Mahkeme'nin bu sonuca varırken dayandığ1 temel gerekçe, taraf sendikaya üye olmayan işçilerin dayanışma aidatı ödeyerek geçmişe dönük haklardan yararlanmalarına imkan tanınmamasının, sendika üyesi olanlarla olmayanlar arasında bir farklılığa yol açacağı; bu ayrımın, işçileri sendikaya üye olmaya "zorlayacağı"; bunun da negatif sendika özgürlüğune aykır1 olduğu; düzenlemenin, dayanışma aidatı ödeyerek sözleşmeden yararlanmayı anlamsız kıldığ1 düşüncesidir (Par. 16; 21; 24; 26) 7 .

Ne var ki, yüksek mahkeme tarafindan yapılan bu tespitler, tartışmaları sona erdirecek gibi görünmemektedir. Nitekim, hem kararı olumlu karşılayan hem de isabetsiz bulan düşünceler gecikmeksizin ortaya çıkmaya başlamıştır (öteden beri düzenlemenin Anayasa'ya aykırılığını savunduğu için kararı olumlu karşılayan, Ekmekçi, 2021: 395; kararda varılan sonucu paylaşmayan, Baskan, 2021: $545 \mathrm{vd).}$

Kanaatimce burada sorun, negatif sendika özgürlüğ̈nü güvence altına alan ve kimsenin sendikaya üye olmaya "zorlanamayacağını" hükme bağlayan anayasal düzenlemeden (AY md. 51 f. 1 son cümle) ne anlaşılması gerektiğini; başka bir ifadeyle, negatif sendika özgürlügünü ihlal eden bir "zorlama"dan ne zaman söz edilebileceğini saptamak noktasında toplanmaktadır:

Bu konuda Alman Hukukunda ileri sürülen bir düşünceye göre, anayasada negatif özgürlükler güvence altına alınırken, aslında birey, belirli görüşleri temsil etmeyi, kanaatlerine aykırı tercihlerde bulunmayı ve belirli kuruluşlara üye olmayı empoze eden otoriter rejim uygulamalarına ${ }^{8}$ karşı korunmak istenmiştir.

7 İki üye tarafından yazılan "karşı oy" gerekçesinde ise, toplu iş sözleşmesinden dayanışma aidatı ödeyerek yararlanabilmek için öncelikle geçerli olarak yapılmış, uygulamaya konulmuş ve halen uygulanmakta olan bir toplu iş sözleşmesinin bulunması gerektiği; sendikaya üye olmayanların toplu iş sözleşmesinden üyeler gibi yararlanmalarının eşitlik ve adalete aykırı olacağ1, sendika üyeliğinin önemini büyük ölçüde kaybettireceği ve sendikaları güçsüzleştireceği; bu durumun da sendikaların varlıklarını koruma özgürlügüne (kolektif sendika özgürlüğüne) aykırılık teşkil edeceği ileri sürülmektedir.

${ }^{8}$ Bilindiği gibi, Almanya'da bütün sendikalar tasfiye edilerek işçiler (10.5.1933 tarihinde kurulan) Deutsche Arbeitsfront (Alman Emek Cephesi) adlı tek bir örgüte üye olmaya (fiilen) zorlanmışlardır. Bu örgüt, daha sonra, sanayici ve esnafin da aynı çatı altında toplanmasıyla, 1939 yılında 25.3 milyon üyeye ulaşan önemli bir güç merkezi hâline gelmiştir. Emek Cephesi hakkında ayrıntılı bilgi için bkz. Nationalsozialismus und zweiter Weltkrieg, Bundeszentrale für politische Bildung, file://C:/Users/1/Downloads/pdflib39529\%20(2).pdf; s. 157; 170; 172; 181; 183; 192-193; 196; 220-221; 223-224; 443. Örgütün yönergesi için bkz. Yale Law School Lillian Goldmann Law Library Nazi Conspiracy and Aggression,

Volume

IV

Document

No.

2271-PS

file://C:/Users/samsung/Documents/Negative $\% 20$ Koalitionsfreiheit/Arbeitsfront $\% 202$ .html 
Anayasa'nın yöneldiği bu amaç, negatif özgürlüklerin kapsamı konusunda da belirleyici olmalıdır. Bu durum, bizi, negatif özgürlüklerin, pozitif özgürlüklerle aynı ölçüde korunmasının gerekmemesi sonucuna götürür (Däubler ve Hege, 1976: 81).

Şüphesiz, bu yaklaşımda bir gerçeklik payı vardır. Ancak, negatif sendika özgürlügünün, sadece otoriter rejim baskıları ile sınırlı bir koruma sağladığını kabul etmek de isabetli görünmemektedir. Burada daha çok, negatif sendika özgürlügünün, sendikaya üye olanlarla olmayanlar arasında tam bir eşitlik sağlanmasını gerektirip gerektirmediği sorusuna yanıt getirilmelidir. Bu soruyu, sendika özgürlügünün tarihsel ve sosyolojik gelişimini dikkate almadan yanıtlamak, kanaatimce bizi isabetli olmayan sonuçlara götürür:

Bir defa, sendika özgürlüğü için yapılan mücadelelere her ülkede daima, bireyin sendikalara karşı korunması değil; tam tersine, bireyin sendikaya üye olabilmesinin güvence altına alınması düşüncesi damga vurmuştur (Kastner, 1953: 162-163; Biedenkopf, 1961: 347). Zira, sendika üyeliği ve sendikal faaliyet, işçilerin işverenler tarafından açık ya da örtülü olarak "cezalandırılması" ve sendikal faaliyetin zayıflatılması riskini de beraberinde getirmiştir (bkz. Baskan, 2021: 552). $\mathrm{Bu}$ tarihsel ve sosyo-ekonomik gerçek, negatif sendika özgürlüğüne tanınacak korumanın ölçüsünü belirlemek bakımından da önem taşımaktadır (Kastner, 1953: 162-163). Bu nedenle, ilke olarak şu hususu tespit etmek gerekmektedir ki, sendikaların özel konumunu belirleyen sosyal koruma ilkesi, negatif sendika özgürlügüne, kolektif sendikal güvenceyi zayıflatan bir işlev yüklenmesine olanak sağlamaz (Badura, 1974: 137). İş hukuku normlarının sosyal niteliği, sendikaya üye olmamayı özendiren bir anlayışla uygulanmalarına elverişli değildir. Sendika üyeliğini dolaylı yoldan "teşvik eden" ya da "özendiren" her uygulamanın hukuka (negatif sendika özgürlüğüne) aykırı sayılması ise, ister istemez, sendikal faaliyetin engellenmesi ya da sınırlandırılması; kısaca kolektif sendika özgürlüğünün zarar görmesi sonucunu yaratır (Meier, 1979: 89). Türk öğretisinde daha önce de isabetle belirtildiği üzere, sendikaların varlıklarını sürdürme ve faaliyette bulunma konusundaki potansiyel güçleri, üye sayıları ile doğru orantılıdır. Bu nedenle, işçiyi sendikaya üye olmamaya yönelten yasal düzenleme ve içtihatlar, kolektif sendika özgürlügünü zedeler (bkz. Eyrenci, 1980: 2; benzer yönde, Narmanlığlu, 1991: 218; Anayasa Mahkemesi'nin kararı ile ilgili olarak aynı yönde, Baskan, 2021: 553). Bu bakımdan, negatif sendika özgürlügünün ihlalinden ancak, üye olma konusunda belli bir "baskı"nın uygulandığı hallerde söz edilebileceği kabul edilir (bkz. Leydecker, 2006: 13). Nitekim, Alman öğretisinde bugün, toplu sözleşme düzeninin yasa gereği sendika üyelerine sağladığı genel yararlar söz konusu olduğu sürece negatif sendika özgürlüğü bakımından bir tereddütten bahsedilemeyeceği vurgulanmaktadır (Brox/Rüthers ve Henssler, 2004:209). Alman Anayasa Mahkemesi de, "negatif sendika özgürlüğünün korunması" ilkesini, bu yaklaşıma paralel biçimde, "bask1 teorisi" (Drucktheorie) olarak adlandırılan (bkz. Seiter, 
1984:102) bir düşünce çerçevesinde değerlendirmektedir: Gerçekten, yüksek mahkeme hem nispeten eski (bkz. Seiter, 1984:102'de anilan kararlar) hem de oldukça yeni tarihli kararlarında istikrarlı olarak, sendikaya üye olmanın sadece teşvik edildiği; fakat bu konuda herhangi bir baskı ya da zorlamanın söz konusu olmadığ1 hallerde negatif sendika özgürlügüne aykırllıktan bahsedilemeyeceğini içtihat etmektedir (BVerfG 3.7.2000, 1 BvR 945/00, Rn. 7; BVerfG, 9.11.2018, 1 BvR 1278/16, Rn. 4; BVerfG 9.7.2020, 1 BvR 719/19, 1 BvR 720/19, Rn. 27)9. Nihayet, Avrupa Insan Hakları Mahkemesi'nin 2.6.2016 tarihli kararında da işveren açısından- aynı yönde bir sonuca ulaşıldığını belirtmek gerekir ${ }^{10}$. Gerçekten, işverenler için Sosyal Yardımlaşma Fonu'na katkıda bulunma yükümlülüğü getiren bir toplu iş sözleşmesinin teşmili üzerine, sendika üyesi olmayan bir işverenin, fon faaliyetlerinde etkili olabilmek için sendikaya üye olmasının gerekeceği; bunun, sendika üyeliğine fiilen teşvik anlamına geldiği ve negatif sendika özgürlüğünü ihlal ettiği iddiasıyla yapmış olduğu başvuruyu, mahkeme, olayda üyelik özendirilmiş olsa da bunun, negatif sendika özgürlügüne aykırılıktan söz edilmesine yol açamayacak kadar "zayıf" (schwach) olduğunu; aykırllık oluşturmaktan çok uzak (too remote) kaldığını belirterek (Par. 57) reddetmiştir (karar ve Alman İş Hukuku bakımından önemi hakkında bkz. Buchholtz ve Heusschmid, 2016: 512 vd; karar hakkinda ayrica bkz. Songu, 2020:203-207) ${ }^{11}$.

\section{Sonuç}

Türk Hukukunda toplu sözleşme sistemi, sendikaların, Amerika Birleşik Devletleri, Fransa ve Avusturya'dan farklı olarak işyerinde çalışan tüm işçiler için değil; fakat Alman Hukuku'na paralel biçimde, "üyeleri” için bağlayıcı kurallar koymaları esasına dayanmaktadır ${ }^{12}$. Sendika üyeliği, bu normların bağlayıcilığı ile ilgili bir

\footnotetext{
9 İnceleme konusu kararında ise Anayasa Mahkemesi, sendika üyeliğine teşvik ile zorlama arasında bir ayırım yapmamakta, ihlal bakımından bazen "teşvik"ten (Par. 21); bazen de "zorlama"dan (Par. 24) söz etmektedir.

${ }^{10}$ Goetech Kancev GmbH/Almanya Kararı, Başvuru No: 23646/09, https://hudoc.echr.coe.int/eng\# $\{\% 22$ display $\% 22:[\% 220 \% 22], \% 22$ languageisocode $\% 22:[$ \%22GER \%22], \%22appno $\% 22:[\% 2223646 / 09 \% 22], \% 22$ documentcollectionid $\% 22:[\% 22$ CHAMBER \%22],\%22itemid \%22:[\%22001-168615\%22]\}

11 Avrupa İnsan Hakları Mahkemesi'nin burada ele alınan sorunu en yakından ilgilendirmesi nedeniyle, sadece anılan kararına değinmekle yetinilmektedir. Mahkeme'nin negatif sendika özgürlügü hakkındaki diğer kararları için bkz. Songu, 2020: 216-237.

12 Anayasa Mahkemesi kararında ise, toplu iş sözleşmesinin, işyerinde çalışan "tüm işçileri temsil etmeye" yetkili olduğu tespit edilen sendika tarafından yapıldığı ifade edilmektedir (Par. 20). Oysa hukukumuzda, sendikalara "işyerinde çalışan tüm işçileri temsil etmek" gibi bir yetki tanınmamıştır. Sözleşmenin, işçilerin salt çoğunluğunu "üye olarak" bünyesinde barındıran sendika tarafından yapılacağının öngörülmüş olması, sadece, hangi sendikanın toplu iş sözleşmesi "akdetmeye yetkili" olduğunun belirlenmesi ile ilgili bir kuraldır. Bu düzenlemenin, sendikayı tüm işçilerin temsilcisi kılmak gibi bir anlam ve işlevi yoktur.
} 
“meşruiyet" temelidir'13. Nitekim, SenTisK md. 39 (1), bu hususu, "Toplu iş sözleşmesinden taraf işçi sendikasının üyeleri yararlanır" ifadesiyle ortaya koymuş bulunmaktadır. Toplu iş sözleşmesini bağıtlayanların -yasa koyucu gibi ve yasa koyucuya tanınan sınırlar çerçevesinde- geçmişe etkili hükümler getirebilmeleri de, hukukî temelini, kendilerine tanınmış olan toplu sözleşme erkinde bulmaktadır.

Diğer taraftan, hukukumuzda, toplu iş sözleşmesinin uygulanma alanı, sendika üyeleriyle sınırlı tutulmamış; üye olmayanların da -İsviçre Hukukunda olduğu gibidayanışma aidatı ödeyerek sözleşmeden yararlanmaları mümkün kılınmıştır. Böylece, negatif sendika özgürlüğünün bütün gerekleriyle sağlandiğı bir sistem kurulmuştur. Sözleşmeye taraf sendikaya üye olmayanların dayanışma aidatı ödemek suretiyle ancak imza tarihinden itibaren toplu iş sözleşmesinden yararlanabilmeleri [Sen'TisK md. 39 (1)] ise, sendikaların sadece üyeleri hakkında (geçmişe etkili) norm koyma erkine sahip olmaları düşüncesine dayanır. Bu bakımdan, sözleşmeden yararlanma konusunda üye olmayanlar aleyhinde bir eşitsizlikten söz etmek mümkün değildir. Ayrıca burada, sendika üyesi olmayanların geçmişe etkili hükümlerden yararlanamamaları nedeniyle Anayasa md. 51 f. 2 anlamında üye olmaya "zorlandıkları" da ileri sürülemez; belki en çok, üyeliğe "teşvik" edildikleri söylenebilir. Ne var ki, böyle bir teşvikin negatif sendika özgürlüğüne aykırı olmadığı hem Alman Federal Anayasa Mahkemesi hem de Avrupa Insan Hakları Mahkemesi tarafindan açıça ortaya konulmuş bulunmaktadır. Bu düşünce, hukukumuz bakımından da emsal teşkil etmelidir. Dayanışma aidatının üyelik aidatı ile aynı tutarda belirlendiği hallerde [Sen'TisK md. 39 (5)] de aynı sonuca varmak gerekir. Esasen sorun, böyle bir "parasal değer karşılaştırması" ile çözümlenmeye hiç de elverişli değildir. Zira, sendika üyeliği, işçiye sadece maddî bir yükümlülük getirmemekte; çok daha önemli olarak, ülkemiz koşullarında ciddî bir "manevî külfet" de yüklemektedir.

Nihayet, sendikaya üye olanlarla olmayanlar arasında tam bir eşitlik sağlanmasının hem hukuken doğru olmadığı hem de kolektif sendika özgürlüğünü zedeleyeceği, her türlü tartışmanın dişındadır.

$\mathrm{Bu}$ teorik esaslar ve pratik gerçekler karşısında sonuç olarak, inceleme konusu Anayasa Mahkemesi kararının isabetli olmadığı düşünülmektedir.

13 Toplu iş sözleşmesi erki konusunda hukukumuzda yapilan ilk çalışmalardan biri olarak, bkz. Sağlam, Fazıl, Türk Hukukunda Toplu İş Sözleşmesi Erki ve Sınırları, AÜSBFD C. 29, Sa. 1, s. 205-2018. Değindiğimiz konuda özellikle, s. 208-209. 


\section{KAYNAKÇA:}

Aktay, Nizamettin/Arıcı, Kadir ve Kaplan Emine Tuncay Senyen (2011): İş Hukuku, 4. Bask1, Ankara.

Badura, Peter (1974): Arbeitsgesetzbuch, Koalitionsfreiheit und Tarifautonomie, RdA (Recht der Arbeit), 1974, Heft 3, s. 129.

Baskan, Esra (2021): Toplu İş Sözleşmesinin Geriye Etkisinden Yararlanma ve Konuya İlişkin Anayasa Mahkemesi'nin 30.12.2020 Tarihli İptal Kararının Değerlendirilmesi, Uluslararası Necmettin Erbakan Hukuk Kongresi, 10-12 Nisan 2021, Bildiri Tam Metin Kitab1, s. 535.

https://sempozyum.erbakan.edu.tr/depo/sem46/files/172edaf1c9b81f3f3a39ac944 2e955b1.pdf

Biedenkopf, Kurt (1961): Zum Problem der negativen Koalitionsfreiheit, JZ, (Juristen Zeitung), 1961, Nr. 11-12, s. 346-354.

Biedenkopf, Kurt (1964): Grenzen der Tarifautonomie, Karlsruhe.

Brox, Hans/Rüthers, Bernd ve Henssler, Martin (2004): Arbeitsrecht, 16. Aufl., Stuttgart.

Buchholtz, Gabriele ve Heuschmid, Johannes (2016): Das Sozialkassenverfahren der Bauwirtschaft verstößt nicht gegen die neg. Koalitionsfreiheit, AuR (Arbeit und Recht) Dezember 2016, Vol. 64. No. 12, s. 512.

Canbolat, Talat (2002): Toplu İş Sözleşmesinden Yararlanamayacak İşçiler, Kamuİş Cilt 6, Say1 4, s. 1. https://www.tuhis.org.tr/pdf/649.pdf

Caniklioğlu, Nurşen (2006): Henüz İmzalanmamış Toplu İş Sözleşmesinden Dayanışma Aidatı Ödeyerek Yararlanma Talebi-Talebin Geçersizliği- Sicil, İş Hukuku Dergisi, Haziran 2006, Say1 2, s. 122.

Çelik, Nuri (1980): İHU TSGLK 7 No.7.

Çelik, Nuri (1990): Toplu İş Sözleşmesinin Uygulanma Alanı, İş Hukuku ve Sosyal Güvenlik Hukuku Türk Milli Komitesi Tarafindan Ankara'da 1990 Yllında Düzenlenen Toplu İş Sözleşmesine İlişkin Temel Sorunlar Semineri, s. 139.

Çelik, Nuri/Caniklioğlu, Nurşen ve Canbolat, Talat (2020): İş Hukuku Dersleri, İstanbul.

Däubler, Wolfgang ve Hege, Hans, (1976): Recht der Koalitionen, Maus, Handbuch des Arbeitsrechts, Koalitionsrecht und Tarifrecht, Schlichtung und Arbeitskampf, Bd. XI-XIII (içinde), XI A.

Ekmekçi, Ömer (1996): Toplu İş Sözleşmesiyle Düzenleme Yetkisi, İstanbul.

Ekmekçi, Ömer (2021) : Toplu İş Hukuku Dersleri, 3. Bası, İstanbul.

Eyrenci, Öner (1980) : İHU TSGLK 7 No.8 ve 10.

Gagawuczuk, Walter (2013): Die kollektive Rechtsgestaltung im Arbeitsrecht, Skriptum Stand Jänner 2013.

https://www.wu.ac.at/fileadmin/wu/o/we4u/text/ar-01.pdf

Gerek, Nüvit (2009): Dayanışma Aidatı Ödeyerek Toplu İş Sözleşmesinden Yararlanma, Sicil İş Hukuku Dergisi, Aralık 2009, Say1 16, s. 137. 
Goldman, Alvin, L (1996): Labor and Employment Law in the United States, Kluwe Law International, Boston-The Hague-London.

Kastner, Fritz (1953): Probleme des Koalitionsrechtes, AuR (Arbeit und Recht), 1953, Vol. 1, No. 6, 1953, s. 161.

Keser, Hakan (1994): Toplu İş Sözleşmesinde Geriye Etkili Yürürlülük ve Yürürlülüğün Başlangıc1, Çimento İşveren Dergisi, C. 8, Sa. 5, Eylül 1994, s. 5.

Leydecker, Philipp (2006): Bonus für Gewerkschaftsmitgliedschaft, AuR (Arbeit und Recht), Vol. 54, No. 1, 2006, s. 11.

Meier, Kurt (1979): Privatrechtlicherschutz gegen Koalitionszwang, Gegenwartsprobleme der Koalitionsfreiheit, Schriften zum schweizerischen Arbeitsrecht, Heft 7, Bern, 1979 (içinde), s. 87.

Narmanlığlu, Ünal (1991): Toplu İş Sözleşmesinin Sadece Taraf Sendika Üyelerine Uygulanan Hükümlerine Tabi Olma, İş Hukuku ve Sosyal Güvenlik Hukuku Türk Milli Komitesi 15. Yıl Armağanı (içinde), İstanbul, s. 179.

Özdemir, Erdem (2002): Toplu İş Sözleşmsinin Geçmişe Etkili Olarak Yürürlüğe Konulması, Kamu-İş, Yargıç Dr. Aydın Özkul'a Armağan, C. 6, Sa. 4, s. 143.

Özkaraca, Ercüment (2014): Toplu İş Sözleşmesinin Geriye Etkisi, İstanbul.

Özkaraca, Ercüment (2016): İş Hukuku ve Sosyal Güvenlik Hukuku Derneği Tarafından Düzenlenen Yargıtay'ın İş Hukuku ve Sosyal Güvenlik Hukuku Kararlarının Değerlendirilmesi, 2014 Semineri, s. 197.

Sachers, Erich (1958): Der kollektive Arbeitsvertrag in Österreich, DRdA (Das Recht der Arbeit), April, 1958, Heft 31, s. 1-9.

Schweingruber Edvin ve Bigler, Walter, F (1985): Kommentar zum Gesamtarbeitsvertrag mit Einschluss der Allgemeinverbindlicherklärung, 3. ergänzte Auflage, Bern.

Seiter, Hugo (1984): Die Rechtsprechung des Bundesverfassungsgerichts zu Art. 9 Abs. 3 GG, AöR (Archiv des öffentlichen Rechts) 1984, Vol. 109, No. 1, s. 88.

Songu, Sezgi, Öktem (2020): Anayasa Mahkemesi'nin Bireysel Başvuru Kararlarında "Sendika Hakkı", İstanbul.

Stöckli, Jean-Fritz (1999): Berner Kommentar, Gesamtarbeitsvertrag und Normalarbeitsvertrag, Art. 356-360 OR.

Subaşı, İbrahim (2009): Sendikalı Olmayan veya Taraf Sendika Üyesi Olmayan İşçilerin Toplu İş Sözleşmesinden Yararlanması, Sicil İş Hukuku Dergisi, Haziran 2009, Sa. 14, s. 172.

Sümer, Haluk, Hadi (2007): Yargıtay'ın İş Hukukuna İlişkin Kararlarının Değerlendirilmesi (2007) Semineri, İş Hukuku ve Sosyal Güvenlik Hukuku Türk Milli Komitesi, İstanbul, s. 207.

Şahlanan, Fevzi (1992): Toplu İş Sözleşmesi, İstanbul. 
Taşkent, Savaş (2004): Toplu İş Sözleşmesi Grev ve Lokavt Yasasında Yapılması Öngörülen Değişiklikler, Galatasaray Üniversitesi ve İstanbul Barosu Tarafindan Düzenlenen "İş Hukuku ve Sosyal Güvenlik Hukukuna İlişkin Sorunlar ve Çözüm Önerileri 2004 Y1lı Toplantısı, İstanbul, s. 257.

Tuncay, Aziz, Can ve Kutsal, Burcu (2019): Toplu İş Hukuku, 7. Bask1, 2019.

Tunçomağ, Kenan ve Centel, Tankut (2008): İş Hukukunun Esasları, 5. Bası, İstanbul.

Uçum, Mehmet ve Okcan, Necdet (2004): 2822 Sayılı Toplu İş Sözleşmesi Grev ve Lokavt Kanununda Değişiklik İçeren Ön Tasarının Hükümleri ve Genel Değerlendirmesi, Legal İş Hukuku ve Sosyal Güvenlik Hukuku Dergisi, 2004, Say1 2, s. 401.

Ulucan, Devrim (1986): Yargıtay'ın İş Hukuku Kararlarının Değerlendirilmesi (1986) Semineri, İş Hukuku ve Sosyal Güvenlik Hukuku Türk Milli Komitesi, İstanbul.

Zöllner, Wolfgang (1983): Arbeitsrecht, 3. Auflage, München. 
